\title{
The Knowledge of Basic Survival Skills Among Preschool Children
}

\section{(Pengetahuan Keterampilan Bertahan Hidup Dasar pada Anak Prasekolah)}

\author{
Abdul Halim Masnan ${ }^{1 *}$, Aqila Zahirah Zulfikri², Hafizul Fahri Hanafi ${ }^{3}$ \\ ${ }^{12}$ Department of Early Childhood Education, Universiti Pendidikan Sultan Idris \\ ${ }^{3}$ Computing Department, Universiti Pendidikan Sultan Idris
}

1abdul.halim@fpm.upsi.edu.my, ${ }^{2}$ aqilazahirah413@gmail.com, ${ }^{3}$ hafizul@fskik.upsi.edu.my

*)corresponding author

\begin{tabular}{ccc}
\hline First received: & Revised: & Final Accepted: \\
15 May 2020 & 02 June 2020 & 30 June 2020 \\
\hline
\end{tabular}

\begin{abstract}
This study aims to understand the knowledge of basic survival skill activities among 6 years old children. This study employs qualitative method with case study design in which interview, observation and document analysis are part of the data collection for this study. The samples of the study are 10 children of 6 years old participated in the outdoor survival activities and a teacher is interviewed to support the data of the study. The findings of the study report that there are differences in pre-post-test conducted and the outdoor survival activities are created and adapted in line with the ability and development of 6 years old children. This study implies that children have lack of knowledge about basic survival skills activities and need to be exposed among children. Thus, this study has provided valuable insights into basic survival activities among children in order to help them improve their knowledge skills.
\end{abstract}

Keywords: Knowledge, Basic Survival Skill, Preschool, Children

\begin{abstract}
Abstrak
Penelitian ini bertujuan untuk memahami pengetahuan kegiatan keterampilan bertahan hidup dasar pada anak-anak berusia 6 tahun. Penelitian ini menggunakan metode kualitatif dengan desain studi kasus dengan wawancara, observasi dan analisis dokumen merupakan teknik pengumpulan data padapenelitian ini. Sampel penelitian adalah 10 anak-anak berusia 6 tahun yang tergabung dalam kegiatan bertahan hidup di luar ruangan dan seorang guru yang diwawancarai untuk mendukung data penelitian. Temuan-temuan pada penelitian ini adalah adanya perbedaan pada pre-post-test yang dilakukan dan kegiatan bertahan hidup di luar ruangan dibuat dan diadaptasi sesuai dengan kemampuan dan perkembangan anak-anak berusia 6 tahun. Studi ini menyiratkan bahwa anak-anak memiliki kekurangan pengetahuan tentang kegiatan keterampilan bertahan hidup dasar dan perlu diekspos di kalangan anak-anak. Dengan demikian, penelitian ini telah memberikan wawasan berharga tentang kegiatan bertahan hidup dasar di antara anakanak guna membantu mereka meningkatkan keterampilan pengetahuan mereka
\end{abstract}

Kata Kunci: Pengetahuan, Keterampilan Bertahan Dasar, Prasekolah, Anak-anak

\section{INTRODUCTION}

Looking at the challenges today, many other countries around the world have expanded the outdoor activities (Bower, Hales, Tate, Rubin, Benjamin, Ward, 2008) to even life-changing-experiences and develop new life skills in life by expanding access to the camp experience (Bento, \& Dias, 2017). Going deeper to these schools and camp programmes, this experience can provide an excellent learning experience for 
the children to learn and develop especially in helping them to learn independence, decision making, socio-emotional skills, character and values building in creative and enriched environment with supervision of the adults in the camp (Abdul Halim Masnan, Elyssa Heinzie Josin, Azizah Zain, \& Nur Arifah Syahindah Zainudin, 2018).

Jean Piaget of Constructivism Theory emphasizes that it is important for children to experience whatever they want to learn about to enable them to construct knowledge (Siegfredsen, 2017). They need real and relevant experiences, with lots of handling, direct contact and playful exploration of materials (Sugiyama, Sahaf, Masters, Okely, Moore, 2010; White, 2014). The best and most permanent type of learning is learning by experience (Acar, 2013; Davies, \& Hamilton, 2018).

Vygotsky's theory of social and cognitive development work together and build each other. The zone of proximal development (ZPD) has been defined as the distance between the actual developmental level as determined by independent problem solving and the level of potential development as determined through problem solving under adult guidance or in collaboration with more capable peers (Vygotsky, 1978 as cited in McLeod, 2012).

In this lesson, children are exposed on prioritising the steps that need to be taken for survival and putting first things first in any dangerous situations whereby they learn about map and compass reading, food preparation and storage, knots, first aid and safety, camping, build a campfire and weather (Moorelands, 2018). This effort of developing those skills are forest school approach helps children to learn how to assess risks and take challenges because these are important life skills and the role of the pedagogy is to support and guide them in how to assess risks and dangerous situations (Maynard, \& Waters, 2007).

In Malaysia, the National Preschool Curriculum Standard (2017) is designed to produce students with 21st century by focusing on thinking skills, living skills and career that are based on moral values practice (Ministry of Education (2017). It is hoped that the students are resilient and empowered through the standard curriculum. One of the elements in integrated learning that helps to develop this 21st century is outdoor activities. Outdoor activities helps to enhance and stimulate children's fitness (Sirard, Trost, Pfeiffer, Dowda, \& Pate, 2005; Stone \& Faulkner, 2014) and intelligence (Waller 2007). Such activities provide opportunities for the children to interact and explore their surroundings (Stephenson, 2007). Through these activities, children's awareness in terms of safety and health are raised and improved (Bento \& Dias, 2017; Hinkley, Crawford, Salmon, Okely, Hesketh, 2008)

It is seen that basic survival skills are seen as important skills and need to be developed among preschool children so that they are capable of physically and mentally. Basic survival skills should have been taught among children as early as possible (Survival Life, 2018). There is a growing interest and awareness in using the outdoors for children's learning and development from parents, local politicians and schools by the research that has been carried out. It is undeniable most international school and non-government agencies conduct such outdoor survival activities among children but this time the researcher is urged to conduct the study in a local preschool to know the level of basic survival skills among children.

\section{METHOD}


Table 1. The Knowledge of Basic Survival

\begin{tabular}{lllllllllll}
\hline Respondent & C1 & C2 & C3 & C4 & C5 & C6 & C7 & C8 & C9 & C10 \\
\hline Pre-test (\%) & 30 & 40 & 53 & 53 & 40 & 40 & 30 & 40 & 53 & 53 \\
\hline Post-test (\%) & 73 & 67 & 67 & 67 & 67 & 80 & 67 & 73 & 73 & 73
\end{tabular}

The objectives of this study is to understand level of knowledge of basic survival skills among 6 years old children. In this study, qualitative case study design was employed. The main focus of qualitative research is to understand, explain, explore, discover and clarify situations, feelings, perceptions, attitudes, values, beliefs and experiences of a group of people and it is flexible and emergent in nature (Kumar, 2014). The data was collected using observation, interview and document analysis. To conduct the process of data collection, worksheet, checklist, lesson plans and a set of interview questions are used as the tools.

A random sampling method was used in this research to meet the objectives of the study. All children in the selected preschool were selected as the population of this study. This study involves a preschool teacher and about 10 children of 6 years old from the population were selected randomly to participate in this study. For this study, the samples are observed during the activities and undergo pre-post test to support the findings of the study.

Responses and observation from worksheet and checklist were analyzed using Microsoft Excel in terms of percentage marks that the children gained before and after the test. Meanwhile lesson plan is analysed by using content analysis and transcript of the interview was analysed by using thematic analysis to find the themes related to the research.

\section{FINDINGS}

The first research question is to know the level of knowledge of basic survival skills among 6 years old children. A prepost test on basic survival skills in the jungle is conducted to know the level of knowledge of basic survival skills among the children. The results in Table 1.1 indicate the percentage marks of each child before and after taking the test.

Table 1 show that there is a difference in marks for every child before and after they participated in the outdoor survival activities. It shows that the percentage marks of each child increase after joining the programme. Before the programme, the lowest percentage mark is $30 \%$ and the highest percentage mark is $53 \%$. This can be seen which there are 2 children who obtained $30 \%$, 4 children with $40 \%$ and the rest are 4 children who got $53 \%$. After joining the outdoor survival activities, the lowest percentage mark is $67 \%$ and the highest percentage mark is $80 \%$.

By referring to Table 1.1, there are 1 child who obtained $80 \%, 4$ children obtained $73 \%$ and 5 children obtained $67 \%$. Therefore, the results of the pre-test show that children have less knowledge and children gain more knowledge from the activities conducted that help them to answer the post-test.

The graph is supported by the findings from the interview session with teacher which claim that the children have low level of knowledge of basic survival skills.

"I have been with the 6 years old children from the beginning of the year and this is almost the end of the school. I observed that most of the 
children have lack of awareness and less knowledge about survival skills especially those related to their safety."

From the excerpt, teacher states that the children have lack of awareness and less knowledge about survival and safety from her observations and experiences of handling the children from the beginning. Based on both findings, it is found that children need to be exposed to outdoor survival activities so that they can learn about basic survival skills that are important in their growth and development.

Teacher claimed that:

"Basic survival skills are basic knowledge of children to try to save themselves and others in any unforeseen circumstances. These may be any unsafe situations and natural disasters such as fire, flood, Tsunami and others. They only know about survival through the topic occupation for example fire fighter. They understand about the roles of fire fighter in saving lives of people. Other than that, the roles of doctor to save lives and prescribe medicines for us."

It's show that important for the teacher to have a good understanding of basic survival skills before they could put them into practice and plan the activities to be conducted during the lessons. Every teacher should include the basic knowledge of survival in lesson on occupation and what they can do based on their roles.

\section{DISCUSSION}

Finding in this study showed that the outdoor survival activities helps children to gain basic survival skills. The changes in percentage marks indicates that children get the knowledge of survival skills and remember what they have learn and apply them in the question given. Teacher $\mathrm{A}$ also claimed that the children need to involve in more survival activities as their skills still need to be improved. Children can understand and need time to improve their level of survival skills over time.

According to Sugiyama, et al (2010) in the outdoors children are more attentive, have better powers of memory and concentrate on activities for longer periods as well as creates opportunities for experiential and situated learning. The findings of the study show that children do have the knowledge of basic survival skills before they join the programme. By guidance from the teacher, they learn more and gain new knowledge through the activities. This process is called scaffolding when children learn with the help of adults. It is important for the adult to support children's learning as it is always critical and support their development by asking the appropriate questions with good explanations and materials (Davies, \& Hamilton, 2018; Maynard, \& Waters, 2007). Abdul Halim Masnan et al (2018) stated that learning occurs when children are given words and idea as well as questions that will lead to their exploration. As they explore by themselves in those activities, they gained not only the experience but also they learn about basic survival skills (Holstermann, Grube, \& Bogeholz, 2010). Moreover, the nature of children showed that they like to explore and curious to know how things happen around them by interaction with the nature.

The findings of the result show more than one effect and not only for the children but also parents and teacher. Basic survival skills are closely related to children's development, skills and knowledge. The children enjoy during the camp especially setting up camp. Most children have not experiencing camping before and they enjoy 
doing the activities. Other than that, the children may have few knowledge but they can understand what have been delivered by the teacher and they can improve the lessons plan. Bento \& Dias, (2017) stated that children learn through real experience will remember the knowledge gained for a long term of period. Over the time, they will be able to understand and apply the knowledge in their daily lives (Stone, \& Faulkner, 2014).

\section{CONCLUSION}

Overall, this study helps more activities and programme on survival skills to be conducted in preschool level. The study informed us that children are aware and have basic knowledge about survival skills. However, it is obvious that children need guidance to understand basic knowledge of survival skills so that they can practice those activities in their daily life (Kwi-Ok Nah \& Waller, 2015).

This study is also hoped to contribute in addressing the possible effects that may help to develop these activities in preschools and to offer some recommendations to enhance children to participate in outdoor survival activities.

\section{ACKNOWLEDGMENT}

This research study was supported by Regional Cluster for Research and Publication (RCRP) through the Universiti Kebangsaan Malaysia (UKM). We thank the Research Management Institute Centre (RMIC) Sultan Idris Education University (UPSI) as the university funder. The title of this study is Pembangunan Modul Pengajaran Pendidikan Alam Sekitar Kanak-Kanak Prasekolah Berasaskan Kemahiran Berfikir Aras Tinggi, project code 2017-0051-106-61 RCRP. We thank all members of the research team who have contributed to this research. We also thank the steering committee, critical informants, teachers, parents and other stakeholders who participated in the study.

\section{REFERENCES}

Abdul Halim Masnan, Elyssa Heinzie Josin, Azizah Zain, \& Nur Arifah Syahindah Zainudin (2018). Environment preschool education module based on higher order thinking skills (HOTS). The Turkish Online Journal of Design, Art and Communication, Sp. Ed., 14421449. Retrieved from http://www.tojdac.org/tojdac/VOLUM E8SPTMSPCL files/tojdac v080SSE193.p $\underline{\mathrm{df}}$

Acar, H. (2013). Learning environments for children in outdoor spaces. Turkey: Karadeniz Technical University.

Bento, G. \& Dias, G. (2017). The importance of outdoor play for young children's healthy development. Porto Biomedical Journal, 2(5), 157-160. Retrieved from https://www.ncbi.nlm.nih.gov/pmc/art icles/PMC6806863/

Bower, J.K., Hales, D.P., Tate, D.F., Rubin, D.A., Benjamin, S.E., \& Ward, D.S. (2008). The childcare environment and children's physical activity. American Journal of Preventive Medicine, 34, 23-29.

Davies, R. \& Hamilton, P. (2018). Assessing learning in the early years' outdoor classroom: examining challenges in practice, Education 3-13, 46(1), 117129, DOI: $\underline{10.1080 / 03004279.2016 .11944}$ $\underline{48}$

Hinkley, T., Crawford, D., Salmon, J., Okely, A.D., \& Hesketh, K. (2008). Preschool 
children and physical activity: A review of correlates. American Journal of Preventive Medicine, 34, 435-441.

Kwi-Ok Nah \& Waller, T. (2015). Outdoor play in preschools in England and South Korea: learning from polyvocal methods. Journal Early Child Development and Care, 185(11-12), 20102025.

DOI: https://doi.org/10.1080/03004430.2015.1 $\underline{028397}$

Maynard, T. \& Waters, J. (2007). Learning in the outdoor environment: a missed opportunity? Early Years, 27(3), 255265, DOI: $10.1080 / 09575140701594400$

McLeod, S.A. (2015). Observation Methods. Simply Psychology. Retrieved from https://www.simplypsychology.org/ob servation.html,

Ministry of Education (2017). National Preschool Curriculum Standard. Malaysia: Bahagian Pembangunan Kurikulum Kementerian Pendidikan Malaysia.

Moorelands (2018). Wilderness survival skills-campers learn about nature and teamwork. Retrieved from https://www.moorelands.ca/wildernes s-survival-skills-campers-learn- natureteamwork/

Seigfredsen, J.W. (2017). Understanding the Danish forest school approach. New York: Routledge.

Sirard, J. R., Trost, S. G., Pfeiffer, K. A., Dowda, M., \& Pate, R. R. (2005). Calibration and evaluation of an objective measure of physical activity in preschool children. Journal of Physical Activity \& Health, 3, 345-357.

Stephenson, A. (2002). Opening up the outdoors: Exploring the relationship between the indoor and outdoor environments of a centre. European Early Childhood Education Research Journal, 10(1), 29-38, DOI: $\underline{10.1080 / 13502930285208821}$

Stone, M.R. \& Faulkner, G.E.J. (2014). Outdoor play in children: Associations with objectively-measured physical activity, sedentary behavior and weight status. Preventive Medicine, 65, 22-127. Retrieved

from https://doi.org/10.1016/j.ypmed.2014.05 .008

Sugiyama, T. Sahaf, R. Masters, J. Okely, T. Moore, G. (2010). Attributes of child care centers and outdoor play areas associated with preschoolers' physical outdoor activity and sedentary behavior, Environment and Behavior, 44(3), 334-349. DOI: https://doi.org/10.1177/001391651 $\underline{0393276}$

Survival Life. (2018). Survival Skills for Kids: Are your kids prepared? Retrieved from https://survivallife.com/survival-tipsskills-to-teach-kids

Kumar, R. (2014). Research Methodology a step by step for beginners. London: SAGE Publications.

Holstermann, N., Grube, D. \& Bogeholz, S. (2010). Hands-on activities and their influence on students' interest. Research in Science Education, 40(5), 743-757. DOI: 10.1007/s11165-009-9142-0

Waller, T. (2007) The trampoline tree and the swamp monster with 18 heads': outdoor play in the foundation stage and foundation phase. Education 313, 35(4), 393407, DOI: $\underline{10.1080 / 03004270701602657}$ 
The Knowledge of Basic Survival... - Abdul Halim Masnan, Aqila Zahirah Zulfikri \& Hafizul Fahri Hanafi

White, J. (2014). Playing and learning outdoors: making provision for high quality experiences in the outdoor environment with children 3-7. New York: Routledge 